\title{
Universal Decision Support System for Selection of MSW Route Optimization Method
}

\author{
Ahmed Omar ${ }^{1}$, Uneb Gazder ${ }^{2}$, Khalil Aljuboori $^{3}$, Nedal Ratrout ${ }^{4}$ \\ ${ }^{1}$ Al Falak Electronic Equipment \& Supplies Co. \\ 31952, Al Khobar \\ Saudi Arabia \\ ${ }^{2}$ Department of Civil Engineering \\ University of Bahrain \\ 32038, Isa Town \\ Bahrain \\ ${ }^{3}$ Department of Civil Engineering \\ British University of Bahrain \\ Saar \\ Bahrain \\ ${ }^{4}$ Department of Civil Engineering \\ King Fahd University of Petroleum and Minerals \\ Dhahran \\ Saudi Arabia
}

Received: July 27, 2021. Revised: November 8, 2021. Accepted: November 25, 2021.

Published: December 29, 2021.

\begin{abstract}
Municipal Solid Waste (MSW) collection utilizes the highest percentage of the MSW management budget. Additionally, choosing a vehicle route optimization method is complex, difficult and does not always yield the most practical approach. There is limited published information about a decision support system (DSS) that assists in selecting the appropriate route optimization algorithm. This study aims to design and develop a universal DSS framework that suggests effective route optimization method(s). The system consists of 21 optimization data items and four criteria that assess the available constraints and recommends the most suitable optimization method(s). The DSS prototype was validated by testing it on the available literature and observing if the suggested method by the system complies with that utilized by the researchers. It was found that the system was able to predict the method which is used in $\mathbf{7 3 \%}$ of studies. Moreover, the system suggested an enhanced version of the methods
\end{abstract}

used in $18 \%$ of studies. It could be concluded that the proposed framework can help to select the best algorithms in almost all existing scenarios that have been used during development. Therefore, it is recommended to use the framework for selecting the appropriate route optimization algorithm for MSW collection.

Key-Words: - MSW management, decision support system, vehicle route optimization, framework, MSW collection

\section{INTRODUCTION}

Municipal Solid Waste (MSW) is an inevitable crisis (especially in developing countries) that significantly affects the environment and the local economy [1]. About 2.01 billion tons per year of MSW are generated globally with approximately 3.40 billion tons per year expected to be generated 
by the year 2050 [2]. As waste quantities show a rapid increase in generation, decision makers need to be aware of the increasing MSW management costs and methods that conduce to cost reductions. The low- and middle-income countries deal with high MSW collection costs that range from $50 \%$ to $90 \%$ of the total MSW budget $[3,4]$. On the other hand, the high-income countries have significantly lower costs for MSW collection (10\%) and most of the budget is allocated for disposal, recycling, treatment, energy recovery, etc. [2]. Route optimization methods have been deployed worldwide to find the best routes for MSW collection with minimum costs and externalities.

Routing optimizations are essential to decision makers to maintain efficient MSW management operations $[5,6]$. Route optimization algorithms are routing solutions utilizing different mathematical models to find the optimal route [7]. The ideal route to a specifically defined location is determined based on a measuring system called the weighted path line. The system works by comparing the weighted priority of the Constraints (Conditions) and Criteria (Objective(s)) for different paths [8]. The optimizations are complex due to the variety of criteria and constraints that are considered and assumed [9]. The constraints vary depending on the user, location, situations, available technologies, software, and hardware. From the literature reviewed (summarized in table 1), the most common criteria sought for optimization are the total travelled distance, total operational time, total costs and environmental impacts. The total costs are concerned with fuel consumption/costs, operational costs, maintenance costs, hauling costs, etc., while the environmental impact mostly focuses on Carbon Dioxide (CO2) emissions. These criteria are linked to each other and the optimization of one parameter can lead to an improvement in others as well.

The research by Le Hoang categorized most of the routing algorithms under four categories [10]. Graph Heuristic is the first category that expresses a map in the form of a graph in which the important locations are presented as nodes that are connected via lines known as Arcs [11-13]. The second category is Integer Programming (IP) which determines the optimal routing solution by employing linear integer programming (for example cutting planes, conic sampling, etc.) and chance constrained programming [14-16]. The third category is the Geographic Information System (GIS) functions that utilize routing algorithms that are built-in within GIS software like the Dijkstra algorithm [17-19]. These algorithms produce solutions in the form of routes with the least costs in terms of distance or time impedances. The final category is Evolutionary Algorithms (EA) which provide approximate solutions in polynomial time [20-22]. EA works by simulating the natural processes of evolution, viz. selection and mutation.

More recently, studies about Hybrid systems suggest the feasibility of integrating algorithms from different categories. This theory was developed to reduce the disadvantages of each standalone category and enrich the yielded optimal solutions $[10,23]$.

Based on the previous literature review, the following gap is being realized. In the presence of a wide set of choices for optimization techniques, it becomes essential that a decision support framework should be developed to help the decision makers in selecting the best algorithm for their situation. Historically, the decision support systems (DSS) have been utilized in many aspects of solid waste management to assist the decision-makers in choosing the appropriate actions [20, 24]. However, the literature on DSS to specifically aid in the selection of a suitable route optimization algorithm for waste collection is limited. Al-Jubori \& Gazder [3] proposed the concept of a universal multi objective framework for route optimization. They considered the cost of MSW collection, social cost, travel distance and time as the optimization objectives. Additionally, it is assumed that optimizing these criteria will result in the reduction of the environmental impact in regards to emission and noise. However, the above-mentioned study did not present any workable framework or prototype for a decision-making framework.

Consequently, a framework for a universal DSS was proposed in the present research which recommends an appropriate route optimization algorithm for MSW collection management which is designed based on available global routing criteria (objectives) and constraints. The proposed DSS framework would be able to reduce the resources and time needed for the method selection as well as suggest the best available alternative option. Moreover, the utilization of the framework does not require prior advanced knowledge of the techniques and algorithms of this field; instead, working knowledge of available scenario is sufficient. 
Table 1. Summary of Literature Reviewed for MSW Collection Route Optimization

\begin{tabular}{|c|c|c|c|c|}
\hline Reference & Place & Optimization Criteria & Algorithm & Category \\
\hline $\begin{array}{ll}\text { (Blazquez } & \& \\
\text { Paredes- } & \\
\text { Belmar)[25] } & \end{array}$ & Chile & $\begin{array}{l}\text { - Total Travelled Distance } \\
\text { - Total Travel Time }\end{array}$ & $\begin{array}{c}\text { Mixed-Integer Linear programming } \\
\text { (MILP) \& Large neighborhood } \\
\text { Search }\end{array}$ & Other \\
\hline $\begin{array}{l}\text { (Bányai et al.) } \\
{[26]}\end{array}$ & Hungary & $\begin{array}{l}\text { - Environmental Impact } \\
\text { - Total Travelled Distance } \\
\text { - Fuel Consumption } \\
\end{array}$ & $\begin{array}{l}\text { Binary Bat Algorithm, part of } \\
\text { Particle Swarm Optimizations }\end{array}$ & $\begin{array}{l}\text { Evolutionary } \\
\text { Algorithms } \\
\text { (EA) }\end{array}$ \\
\hline $\begin{array}{l}\text { (Louati et al.) } \\
{[27]}\end{array}$ & Tunisia & $\begin{array}{l}\text { - Total Travelled Distance } \\
\text { - Total Travel Time }\end{array}$ & $\begin{array}{c}\text { Modified Dijkstra Algorithm in } \\
\text { ArcGIS }\end{array}$ & GIS-Functions \\
\hline $\begin{array}{l}\text { (Dao-Tuan et al.) } \\
{[7]}\end{array}$ & Vietnam & $\begin{array}{l}\text { - Fuel Consumption } \\
\text { - Carbon Dioxide Emissions } \\
\text { - Total Costs }\end{array}$ & $\begin{array}{l}\text { Integer linear programming } \\
\text { (ILP) and MILP }\end{array}$ & $\begin{array}{c}\text { Integer } \\
\text { Programming } \\
\text { (IP) }\end{array}$ \\
\hline $\begin{array}{ll}(\text { Kamal } & \& \\
\text { Youlla, })[28] & \\
\end{array}$ & Indonesia & - Total Costs & $\begin{array}{l}\text { Branch and Bound integer } \\
\text { programming in VRP }\end{array}$ & IP \\
\hline $\begin{array}{l}\text { (Nesmachnow et } \\
\text { al.)[29] }\end{array}$ & Uruguay & - Total Travelled Distance & NSGA-II and SPEA-2 & EA \\
\hline (Akhtar et al.)[30] & Malaysia & $\begin{array}{l}\text { - Total Costs } \\
\text { - Environmental Impacts }\end{array}$ & $\begin{array}{c}\text { Backtracking } \\
\text { Search Algorithm (BSA) }\end{array}$ & EA \\
\hline $\begin{array}{ll}\text { (Assaf } & \& \\
\text { Saleh)[31] } & \end{array}$ & Palestine & - Total Travelled Distance & Genetic Algorithm (GA) method & EA \\
\hline $\begin{array}{l}\text { (Nguyen-Trong et } \\
\text { al.)[23] }\end{array}$ & Vietnam & - Total Costs & $\begin{array}{c}\text { Integrating GIS, equation } \\
\text { based model plus agent-based } \\
\text { model }\end{array}$ & Others \\
\hline $\begin{array}{l}\text { (Le Hoang \& } \\
\text { Louati) }[32]\end{array}$ & Vietnam & $\begin{array}{l}\text { - Total Travelled Distance } \\
\text { - Total Travel Time }\end{array}$ & GIS & GIS-Functions \\
\hline (Paul et al.)[33] & India & - Total Costs & GIS & GIS-Functions \\
\hline $\begin{array}{l}\text { (Sanjeevi } \quad \& \\
\text { Shahabudeen)[34] }\end{array}$ & India & $\begin{array}{l}\text { - Total Travelled Distance } \\
\text { - Total Travel Time }\end{array}$ & GIS & GIS-Functions \\
\hline (Xue \& Cao) $[35]$ & Singapore & $\begin{array}{l}\text { - Total Travel Time } \\
\text { - Population Exposure } \\
\text { - Reduce Crash Probability }\end{array}$ & $\begin{array}{l}\text { Hybrid, Ant Colony Optimization } \\
\text { (ACO) and GIS }\end{array}$ & Others \\
\hline (Le Hoang)[10] & Vietnam & $\begin{array}{l}\text { - Maximize Quantity of } \\
\text { MSW Collected }\end{array}$ & $\begin{array}{c}\text { Hybrid, Chaotic Particle and } \\
\text { GIS }\end{array}$ & Others \\
\hline $\begin{array}{l}\text { (Malakahmad et } \\
\text { al.)[36] }\end{array}$ & Malaysia & $\begin{array}{l}\text { - Total Travelled Distance } \\
\text { - Total Travel Time }\end{array}$ & GIS & GIS-Functions \\
\hline$\left(\mathrm{O}^{\prime}\right.$ Connor $)[8]$ & USA & $\begin{array}{l}\text { - Total Travel Time } \\
\text { - Total Travelled Distance }\end{array}$ & GIS & GIS-Functions \\
\hline $\begin{array}{l}\text { (Kanchanabhan et } \\
\text { al.) [37] }\end{array}$ & India & - Total Travelled Distance & GIS & GIS-Functions \\
\hline (Makan et al.)[38] & Morocco & $\begin{array}{l}\text { - Collection Costs } \\
\text { - Maximize Quantity of } \\
\text { MSW Collected }\end{array}$ & $\begin{array}{c}\text { Custom software "Container } \\
\text { Collector" utilizing Tabu Search } \\
\text { Algorithm }\end{array}$ & Others \\
\hline $\begin{array}{ll}\text { (Chalkias } & \& \\
\text { Lasaridi)[17] } & \\
\end{array}$ & Greece & $\begin{array}{l}\text { - Total Travel Time } \\
\text { - Total Travelled Distance }\end{array}$ & GIS & GIS-Functions \\
\hline $\begin{array}{l}\text { (Apaydin } \\
\text { Gonullu)[39] }\end{array}$ & Turkey & $\begin{array}{l}\text { - Total Costs } \\
\text { - Total Travelled Distance } \\
\text { - Total Travel Time }\end{array}$ & $\begin{array}{l}\text { Integrating Route View Pro } \\
\text { software with GIS }\end{array}$ & Others \\
\hline $\begin{array}{l}\text { (Karadimas et } \\
\text { al.)[19] }\end{array}$ & Greece & - Total Travelled Distance & GIS & GIS-Functions \\
\hline$($ Agha $)[40]$ & Palestine & - Total Travelled Distance & Mixed-Integer programming & IP \\
\hline
\end{tabular}


The proceeding contents of this paper are organized as follows. Section 2 presents an insight into the literature concerning route optimization for vehicles. Section 3 describes the development of the proposed DSS framework. Section 4 focuses on the result obtained and its discussion. Finally, section 5 provides the conclusion and discusses possible future works for this research.

\section{VEHICLE ROUTE OPTIMIZATION}

About 70 peer-reviewed journal articles, conference proceedings, reports and books were accessed. The main repositories from which the papers were searched and obtained were Elsevier, Springer, Google Scholar, Research Gate, and others. Some keywords utilized for the literature search were MSW collection optimization, MSW vehicle route optimization, decision support system for MSW collection. Additionally, many of the researches are interconnected through referencing which aided the authors in the literature search. From the literature review, 45 relevant articles were selected for this research, of which, $22 \mathrm{MSW}$ collection route optimization articles are selected for the global DSS case-study and tests (table 1).

\section{A. Route Optimization Algorithms}

The literature on route optimization algorithm comparisons is scarce and requires intensive research to study the impact between multiple algorithms due to variants, application techniques and mathematical modeling. For the scope of this research, the selection was limited to three types of algorithms as the pros and cons of each algorithm can be determined from the existing body of literature. The types of algorithms embedded in these chosen methods which are GIS, Hybrid and IP. The method selection is based on the popularity and availability of sufficient information in the literature.

The GIS method provides a combined package that contains both the platform and the routing algorithm. GIS platform is capable of storing, retrieving, analyzing and displaying spatial and non spatial data [41]. The GIS algorithm core is the Dijkstra algorithm, which dates back to 1959 [42]. However, the Dijkstra algorithm was modified to be utilized in route optimization. The optimization done by this algorithm is calculated based on the estimated shortest/low-cost distance or time impedances.

The second selected optimization method is the Hybrid method. For the proposed DSS, the hybrid method was considered as a combination of evolutionary algorithms (EA) and GIS platform. The purpose of this method is to integrate the analytical power of EA and GIS platform for data processing and visualization capabilities. In literature, EA and hybrid models are applied in advanced optimization applications (such as dynamic routing, smart systems, etc.) as well as unique optimization criteria, such as; vehicle crash risk [10, 35]. Lastly, IP is an ancient method, compared to the previously discussed methods in the field of route optimization [43]. This method is suitable for small to medium scale problems. Any increase in problem size and complexity would result in higher computational time and increased difficulty in generating solution(s). A summary of the selected methods along with the pros and cons are shown in table 2 .

\section{B. Required Variables and Constraints}

In the reviewed literature, it was observed that different algorithms can accommodate the same variables (data). The optimization data incorporated in this research were selected from popular and recurrent features found in waste collection literature. These data were identified and collected from the contents (data, constraints, objectives, assumptions and mathematical modeling) of the literature presented in table 1 . The most prevailing data found in MSW vehicle routing optimization are Map Availability, Bin Information (location and capacity), Vehicle Capacity and Facilities' Location. Furthermore, the optimization data utilized for the DSS proposition is summarized in table 3 . Additionally, table 3 also indicates the number of studies, within the reviewed literature, in which each data has been used. 
Table 2. Summary of the selected Optimization Methods

\begin{tabular}{|c|c|c|c|}
\hline Method & $\begin{array}{l}\text { Optimization } \\
\text { criteria }\end{array}$ & Pros & Cons \\
\hline $\begin{array}{c}\text { GIS } \\
\text { (Modifi } \\
\text { ed } \\
\text { Dijkstra } \\
\text { ) }\end{array}$ & $\begin{array}{l}\text { - Total } \\
\text { Travelled } \\
\text { Distance } \\
\text { - Total } \\
\text { Travel } \\
\text { Time }\end{array}$ & $\begin{array}{l}\text { - Visualizatio } \\
\mathrm{n} \\
\text { capabilities } \\
\text { - Spatial and } \\
\text { non-spatial } \\
\text { database } \\
\text { managemen } \\
\mathrm{t} \\
\text { - Allows road } \\
\text { network } \\
\text { modeling to } \\
\text { incorporate } \\
\text { impedances } \\
\text { and } \\
\text { restrictions. }\end{array}$ & $\begin{array}{l}\text { - Limited } \\
\text { to static } \\
\text { parameter } \\
\text { models } \\
\text { - Solver } \\
\text { not } \\
\text { suitable } \\
\text { for route } \\
\text { optimizat } \\
\text { ion for a } \\
\text { large } \\
\text { cluster of } \\
\text { points } \\
\text { - Require } \\
\text { modificat } \\
\text { ions and } \\
\text { program } \\
\text { ming } \\
\text { knowledg } \\
\text { e for } \\
\text { advanced } \\
\text { applicatio } \\
\text { ns }\end{array}$ \\
\hline $\begin{array}{c}\text { Hybrid } \\
\text { (EA + } \\
\text { GIS) }\end{array}$ & $\begin{array}{l}\text { - Total } \\
\text { Travelled } \\
\text { Distance } \\
\text { (Advanced } \\
\text { application } \\
\text { s) } \\
\text { - Environme } \\
\text { ntal Impact } \\
\text { (Advanced } \\
\text { application } \\
\text { s) } \\
\text { - Vehicle } \\
\text { Crash Risk }\end{array}$ & $\begin{array}{l}\text { - Visualizatio } \\
\mathrm{n} \\
\text { capabilities } \\
\text { - Powerful } \\
\text { and efficient } \\
\text { EA } \\
\text { processing } \\
\text { - Quality of } \\
\text { final } \\
\text { solution(s) } \\
\text { and faster } \\
\text { computation } \\
\text { al time }\end{array}$ & $\begin{array}{l}\text { - Difficult } \\
\text { to } \\
\text { integrate } \\
\text { and } \\
\text { program } \\
\text { the model } \\
\text { - Technical } \\
\text { expertise } \\
\text { in the } \\
\text { optimizat } \\
\text { ion field } \\
\text { required }\end{array}$ \\
\hline $\begin{array}{c}\text { Integer } \\
\text { program } \\
\text { ming } \\
\text { (MILP } \\
\& \text { ILP) }\end{array}$ & $\begin{array}{l}\text { - Environme } \\
\text { ntal Impact }\end{array}$ & $\begin{array}{l}\text { - Legacy } \\
\text { method } \\
\text { (Well } \\
\text { established } \\
\text { in past and } \\
\text { present } \\
\text { literature) }\end{array}$ & $\begin{array}{l}\text { - Increased } \\
\text { difficulty } \\
\text { and } \\
\text { computati } \\
\text { onal time } \\
\text { with } \\
\text { respect to } \\
\text { problem } \\
\text { complexit } \\
\text { y } \\
\text { - No visual } \\
\text { output } \\
\text { - Yields } \\
\text { partial } \\
\text { solution } \\
\text { in reality } \\
\text { applicatio } \\
\text { ns }\end{array}$ \\
\hline
\end{tabular}

*Source: All literature in Table 1 \& (Sulemana et al., 2018)[44]
Table 3. Summary of Available Data in The Reviewed Literature (out of 22)

\begin{tabular}{|c|c|c|}
\hline $\begin{array}{l}\text { S. } \\
\mathbf{N} \\
\text { o. }\end{array}$ & Route Optimization Data & $\begin{array}{l}\text { Quant } \\
\text { ity }\end{array}$ \\
\hline 1 & 1. Digital Map & 22 \\
\hline 2 & 2. Bin Locations & 22 \\
\hline 3 & 3. Bin Capacities & 22 \\
\hline 4 & 4. MSW Collection Vehicle Capacity & 22 \\
\hline 5 & 5. Facilities Location & 22 \\
\hline 6 & $\begin{array}{l}\text { 6. Map Zones (Districts, Wards, Blocks, } \\
\text { etc.) }\end{array}$ & 11 \\
\hline 7 & $\begin{array}{l}\text { 7. Spatial Population Data (Number, } \\
\text { Density, Distribution) }\end{array}$ & 10 \\
\hline 8 & $\begin{array}{l}\text { 8. Road Attributes (Name, Width, Lane, } \\
\text { Etc.) }\end{array}$ & 6 \\
\hline 9 & 9. Vehicle or Road Speed & 16 \\
\hline 10 & $\begin{array}{l}\text { 10. Road Level or Elevation at the } \\
\text { intersections }\end{array}$ & 1 \\
\hline 11 & 11. One-way Roads & 4 \\
\hline 12 & 12. MSW Bin Smart Sensors & 2 \\
\hline 13 & 13. Digital Terrain Model (DTM) & 2 \\
\hline 14 & 14. MSW Vehicle GPS Tracker & 3 \\
\hline 15 & 15. MSW Vehicle Smart Sensors & 1 \\
\hline 16 & 16. MSW Vehicle Specification & 8 \\
\hline 17 & 17. Traffic Signals \& Stop Signs Location & 4 \\
\hline 18 & 18. Crash Data (Black Spots) & 1 \\
\hline 19 & 19. Number of MSW Collection vehicles & 21 \\
\hline 20 & 20. Traffic Volumes & 3 \\
\hline 21 & 21. Daily Waste Generated Quantity & 21 \\
\hline
\end{tabular}

\section{Scheduling}

The scheduling techniques incorporated in this research are Static and Dynamic scheduling. The static scheduling method works on a fixed operations schedule for MSW collection and transportation vehicles. It is applied periodically (Daily, Weekly, Monthly, etc.) to reevaluate the current situation and determine an optimum or semi optimum route(s). On the contrary, dynamic scheduling utilizes real time data using smart sensors to determine the optimal route based on waste generation and collection demand. It requires both the MSW vehicles and bins to be equipped with sensors. Cameras, weight scale, RFID (tags \& readers) and GPS trackers are some of the sensors utilized in MSW collection and transportation 
monitoring. Such systems yield potential MSW collection on demand which yields a more efficient and effective MSW management system while optimizing costs [45].

\section{III.DSS DESIGN}

This section describes the components of the proposed DSS along with the embedded assumptions and limitations to the system. Moreover, the prototype for the proposed system is also presented.

\section{A. Decision Support System Architecture}

The DSS structure and components (illustrated in figure 1) were proposed as a new comprehensive operational framework with respect to global criteria and constraints. The framework consists of four main components. The DSS's first component is the input data which consists of optimization data availability assessment and criteria prioritization. Similar to the optimization data, the optimization criteria were chosen based on popularity and recurrence in the reviewed literature. In addition, an MSW collection service provider (Urbaser) was interviewed to refine the selection of the optimization data and criteria with respect to realworld applications. The optimization data were utilized as constraints for the operation of the DSS. One of the main tasks of the first component is to Identify the minimum required data to run the DSS. Please, leave two blank lines between successive sections as here.

From the literature, four optimization criteria (objectives) were chosen for the DSS which are; Environmental Impact, Total Travel Distance, Total Travel Time and Vehicle Crash Risk. All selected criteria can indirectly affect the cost, positively or negatively. Each criterion requires one or more essential optimization data to be eligible for route optimization. The ability to optimize each criterion may require additional data depending on the definition and intended usage [20] (Ferreira et al., 2015). The selected criteria for this research are defined as follows:

- Environmental Impact: The effect of the byproducts (emissions, mostly carbon dioxide) produced from the MSW vehicles during the collection and transportation operations [26].

- Total Travelled Distances: The total distance traversed by the MSW vehicles per day (in some cases, per shift) of MSW collection and transportation operation [27].

- Total Travel Time: The overall time taken by the MSW collection and transportation vehicles per day to accumulate the waste and deliver it to its designated location [8].

- Vehicle Crash Risk: The frequency of the Black Spots (crash locations) per road. The rise in black spot frequency increases the risk of utilizing that road. Vehicle crash risk is considered in route optimization when the stakeholders' (mainly company employees and the public) safety is a concern [35].

The second component of the DSS framework is condition configuration and situation assessment. Minimum requirements and criteria conditions (required optimization data) are configured in this component. Additionally, the assessment of the client's available optimization data with the configured condition is performed in this component. The minimum required data for the DSS to produce a recommendation are the first five optimization data listed in table 3 . These data were observed repetitively in most literature for basic vehicle route optimization, especially on Capacitated Vehicle Routing Problem (CVRPs) models. Furthermore, these data serve as the essential conditions for the total travelled distance criterion optimization in this research. The capacities of both MSW bins and vehicles have been accommodated as limiters to produce an effective solution(s) for a close to real-life scenario [46, 47]. This is due to the ease of obtaining the available capacity data from the waste collection service provider at no cost or time.

The environmental impact is considered in route optimization analysis when vehicle specifications are available. The specifications assist in identifying vital data such as fuel type and average fuel consumption which affects the emissions quantity. The vehicle crash risk criterion requires the identification of frequent crash locations known as blackspots. In addition, historical crash data can also be utilized in the optimization analysis. Finally, the total time travelled by vehicles requires speed data and road distance. For the scope of this study, real time variable speed data was not considered.

The best-case scenario for the proposed DSS framework is that all the optimization data are available. This indicates that the client has a strong established MSW collection and transportation 
monitoring system. In addition, the client can implement more advanced optimization methods that can result in better optimal solutions. For all cases subjected to the DSS, the recommendation setup will include possible scheduling techniques in addition to suitable route optimization method(s).

The third component of the DSS framework is the production of the recommended optimization setup. The recommended method is produced based on the data availability and prioritized criteria from previous components. In the literature, it is observed that the selection of the optimization algorithm was strongly influenced by the preferred criteria (objective). Furthermore, the proposed universal DSS is plausible due to the similar basic fundamental of the weighted path line and the algorithm's ability to accommodate the same data variables. The main difference noted is the mathematical modeling of each method to calculate the weighted path line.

The final component of the DSS framework is the route optimization application. In this component, the decision-maker is required to apply the recommended routing algorithm to produce initial optimized routes. Any recommended routing technique may produce single or multiple optimized routes based on the optimization data availability and selected criteria. The decision makers can assess the optimized route(s) by comparing the initially optimized route solutions against the current local collection active routes with respect to the desired parameters. If the solutions are unsatisfactory, the DSS can be revisited with new additional data. These added data should unlock better routing recommendation options to achieve the desired optimization targets. When more data is provided to the DSS, more advanced options and features can be incorporated to produce a more effective and efficient optimized vehicle routing solution(s).

\section{B. Prototype}

A prototype program of the DSS was developed in MATLAB 2018b student edition. The program consists of input and output phases. The input phase is a set of 21 questions to identify the availability of the constraints in table 3. Each question represents an individual optimization data. For simplicity, the answers are required in the form of " 1 " (Yes) and "2" (No). Furthermore, the user is presented with a list of the predefined optimization criteria in the DSS which should be ranked from "1" (TopPriority) to "4" (Least-Priority). The development of the program incorporated error-proofing (blank answers, repetition, unnecessary characters, etc.) to reduce any chances of issues that might occur. The best- and worst-case scenarios with their responses were also included. The developed program was designed to be flexible to incorporate additional criteria, constraints and conditions for future researches. All of the input data are analyzed by the program to produce a suitable route optimization technique. The developed framework does not require any advanced knowledge of optimization techniques and algorithms, rather, working knowledge of available scenarios is sufficient.

The output phase yields two distinct recommendations. The first recommendation is a suitable scheduling technique (Static or Dynamic). The second recommendation is the suggested route optimization method for the top-priority criteria if sufficient data is available. Moreover, the user can view the suggested optimization method for the other pre-defined criteria if eligible for optimization. A summary of the available data as well as the priorities set by the user will be presented. The summary and results can be saved in .XLSX format as well as printed.

\section{RESULTS AND DISCUSSION}

The prototype program of the DSS was tested to ensure proper operation and suitable output recommendations. The test subjects were all of the researches presented in table 1 , which were tested individually. A list of available optimization data for each research was collected as an input for the program. The priority selection for criteria is based on each research's objective(s). Moreover, any additional criteria that were not mentioned in the tested studies were given a priority arbitrarily. The designed DSS program assesses the presented data and the priorities of the criteria to produce the recommended route optimization setup. The testing procedure is as follows:

- Each research's input data along with the criteria priorities is fed to the program.

- The test trial is considered a match if the program yields the same algorithm as originally utilized in the research.

- The test trial is deemed mismatched in case of differences in the algorithms.

The test's theory is that the DSS design was based on the contents of the literature reviewed. Thus, the DSS should be able to predict a suitable algorithm for each corresponding study. The success of the designed DSS is summarized in table 4. 


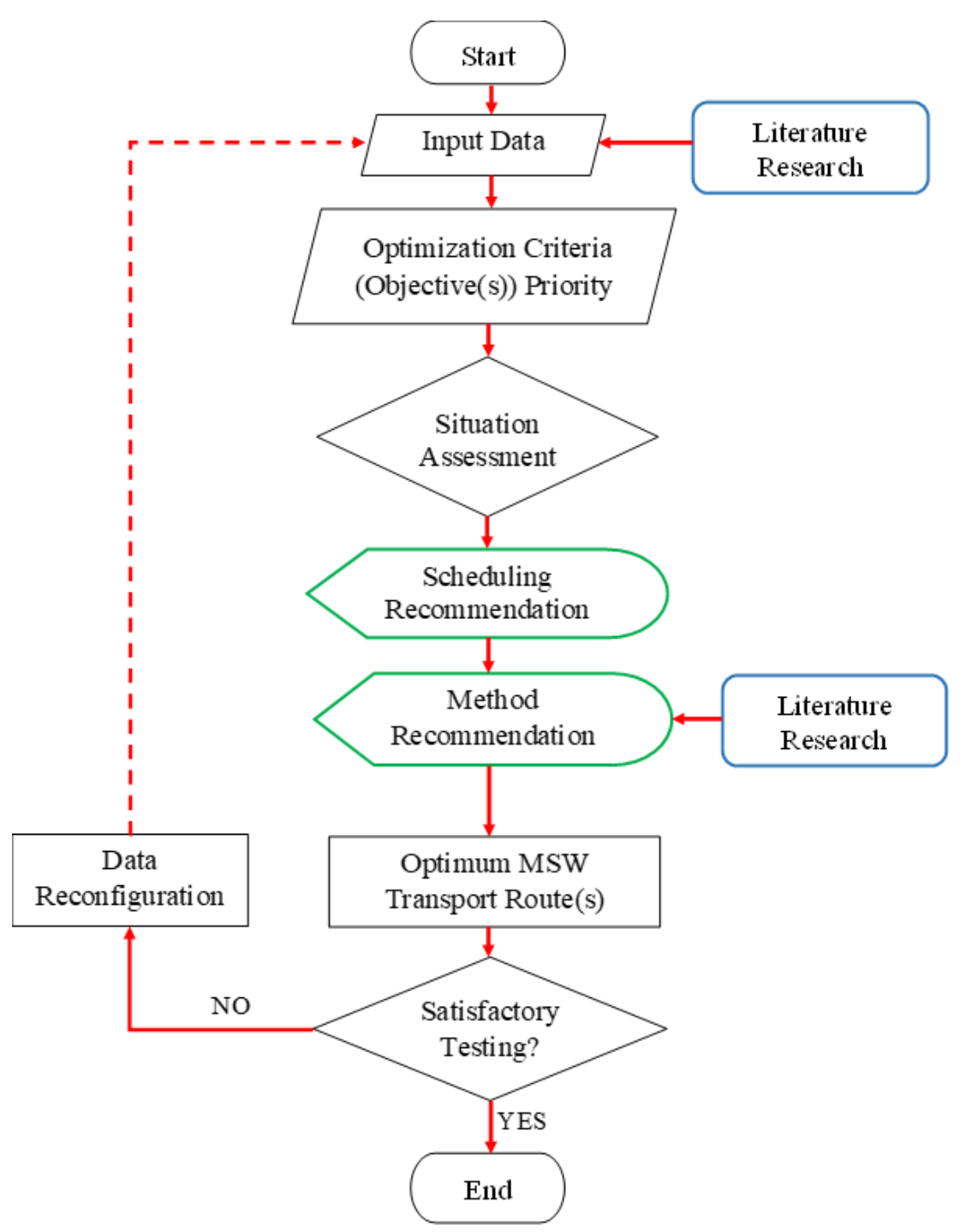

Fig. 1 The Proposed Route Optimization Decision Support Framework 
Table 4. Decision Support System Testing Results

\begin{tabular}{|c|c|c|c|}
\hline $\begin{array}{l}\text { Author/ } \\
\text { reference }\end{array}$ & $\begin{array}{l}\text { Optimization Criteria } \\
\text { (Optimize/Minimize) }\end{array}$ & Original Algorithm & $\begin{array}{l}\text { DSS Matching } \\
\text { with Research }\end{array}$ \\
\hline $\begin{array}{l}\text { (Blazquez \& } \\
\text { Paredes-Belmar)[25] }\end{array}$ & $\begin{array}{l}\text { - Total Travelled Distance } \\
\text { - Total Time Travelled }\end{array}$ & $\begin{array}{c}\text { Mixed-Integer Linear programming } \\
\text { (MILP) \& Large neighborhood } \\
\text { Search } \\
\end{array}$ & NO \\
\hline (Bányai et al.)[26] & $\begin{array}{l}\text { - Environmental Impact } \\
\text { - Total Travelled Distance }\end{array}$ & $\begin{array}{l}\text { Binary Bat Algorithm, part of } \\
\text { Particle Swarm Optimizations }\end{array}$ & $\begin{array}{c}\text { NO } \\
\text { (Partial) }\end{array}$ \\
\hline (Louati et al.)[27] & $\begin{array}{l}\text { - Total Travelled Distance } \\
\text { - Total Time Travelled }\end{array}$ & $\begin{array}{c}\text { Modified Dijkstra Algorithm in } \\
\text { ArcGIS }\end{array}$ & YES \\
\hline (Dao-Tuan et al.)[7] & - Environmental Impact & Integer Programming & YES \\
\hline $\begin{array}{l}\text { (Kamal } \\
\text { Youlla)[28] }\end{array}$ & $\begin{array}{l}\text { - Total Travelled Distance to Reduce } \\
\text { Costs }\end{array}$ & Integer Programming & NO \\
\hline $\begin{array}{l}\text { (Nesmachnow et } \\
\text { al.)[29] }\end{array}$ & - Total Travelled Distance & $\begin{array}{l}\text { 1. NSGA-II } \\
\text { 2. SPEA-2 }\end{array}$ & $\begin{array}{c}\text { NO } \\
\text { (Partial) }\end{array}$ \\
\hline (Akhtar et al.)[30] & - Environmental Impacts & $\begin{array}{c}\text { Backtracking } \\
\text { Search Algorithm (BSA) }\end{array}$ & $\begin{array}{c}\text { NO } \\
\text { (Partial) }\end{array}$ \\
\hline (Assaf \& Saleh)[31] & - Total Travelled Distance & Genetic Algorithm (GA) method & $\begin{array}{c}\text { NO } \\
\text { (Partial) }\end{array}$ \\
\hline $\begin{array}{l}\text { (Nguyen-Trong et } \\
\text { al.)[23] }\end{array}$ & $\begin{array}{l}\text { - Total Travelled Distance to Reduce } \\
\text { Costs }\end{array}$ & $\begin{array}{c}\text { Integrating GIS, equation } \\
\text { base model plus agent-based model }\end{array}$ & NO \\
\hline $\begin{array}{l}\text { (Le Hoang \& } \\
\text { Louati)[32] }\end{array}$ & $\begin{array}{l}\text { - Total Travelled Distance } \\
\text { - Total Time Travelled } \\
\end{array}$ & GIS & YES \\
\hline (Paul et al.)[33] & $\begin{array}{l}\text { - Total Travelled Distance to Reduce } \\
\text { Costs }\end{array}$ & GIS & YES \\
\hline $\begin{array}{ll}\text { Sanjeevi } & \& \\
\text { Shahabudeen }[34] & \\
\end{array}$ & $\begin{array}{l}\text { - Total Travelled Distance } \\
\text { - Total Time Travelled } \\
\end{array}$ & GIS & YES \\
\hline$($ Xue \& Cao) $[35]$ & $\begin{array}{l}\text { - Total Time Travelled } \\
\text { - Vehicle Crash Risk }\end{array}$ & $\begin{array}{l}\text { Hybrid, Ant Colony Optimization } \\
\text { (ACO) and GIS }\end{array}$ & YES \\
\hline (Le Hoang)[10] & $\begin{array}{l}\text { - Maximize Quantity of MSW } \\
\text { Collected to optimize total Travel } \\
\text { Distance and Time }\end{array}$ & $\begin{array}{l}\text { Hybrid, Chaotic Particle and } \\
\text { GIS }\end{array}$ & YES \\
\hline $\begin{array}{l}\text { (Malakahmad } \\
\text { al.)[36] }\end{array}$ & $\begin{array}{l}\text { - Total Travelled Distance } \\
\text { - Total Time Travelled }\end{array}$ & GIS & YES \\
\hline (O'Connor) $[8]$ & $\begin{array}{l}\text { - Total Time Travelled } \\
\text { - Total Travelled Distance } \\
\end{array}$ & GIS & YES \\
\hline $\begin{array}{l}\text { (Kanchanabhan et } \\
\text { al.) [37] }\end{array}$ & - Total Travelled Distance & GIS & YES \\
\hline (Makan et al.)[38] & $\begin{array}{l}\text { - Optimize collection cost by } \\
\text { shortest routes with respect to time }\end{array}$ & $\begin{array}{c}\text { Custom software "Container } \\
\text { Collector" utilizing Tabu Search } \\
\text { Algorithm }\end{array}$ & NO \\
\hline $\begin{array}{l}\text { (Chalkias } \\
\text { Lasaridi)[17] }\end{array}$ & $\begin{array}{l}\text { - Total Time Travelled } \\
\text { - Total Travelled Distance }\end{array}$ & GIS & YES \\
\hline $\begin{array}{l}\text { (Apaydin } \\
\text { Gonullu) }[18]\end{array}$ & $\begin{array}{l}\text { - Total Travelled Distance } \\
\text { - Total Time Travelled }\end{array}$ & $\begin{array}{l}\text { Integrating Route View Pro } \\
\text { software with GIS }\end{array}$ & NO \\
\hline $\begin{array}{l}\text { (Karadimas et } \\
\text { al.)[19] }\end{array}$ & - Total Travelled Distance & GIS & YES \\
\hline$($ Agha $)[40]$ & - Total Travelled Distance & Integer Programming & NO \\
\hline
\end{tabular}


The test results shown in figure 2 indicate that $55 \%$ of the tested literature was recommended the same algorithm by the DSS as utilized originally. Furthermore, $18 \%$ of the subjects, employed evolutionary algorithms while the DSS recommended using the hybrid method (Evolutionary Algorithms integrated with GIS platform). Hence, the main difference was the lack of a visualization platform in those researches. Since DSS recommended a better alternative, with the graphical platform, therefore it is considered successful. Furthermore, $14 \%$ of cases, among the $18 \%$ mismatched, used IP while the DSS recommends the GIS method or Hybrid for advanced optimization applications. The latter can optimize the routes with a simpler technique that involves less computational time and resources. It could also be said that the DSS provided a more enhanced recommendation than the actual method used in these studies. This points to the ability of the DSS to guide the client towards the best recommendation for specific situations.

About $9 \%$ of the tested researches utilized custom developed software based on different algorithms. Consequently, they could not be predicted by the DSS program. The difference between those options and the recommendations has not been tested as the authors have no access to those tools, hence, it was considered out of the research's scope. Furthermore, agent based intelligent models were utilized in one of the cases, among the unsuccessful. These models are relatively new in the vehicle route optimization field and only a few researches have tested these methods compared to the ones defined in this research. Hence, such intelligent models can be added to the DSS, if and when more, research is pursued with them for MSW collection routes.

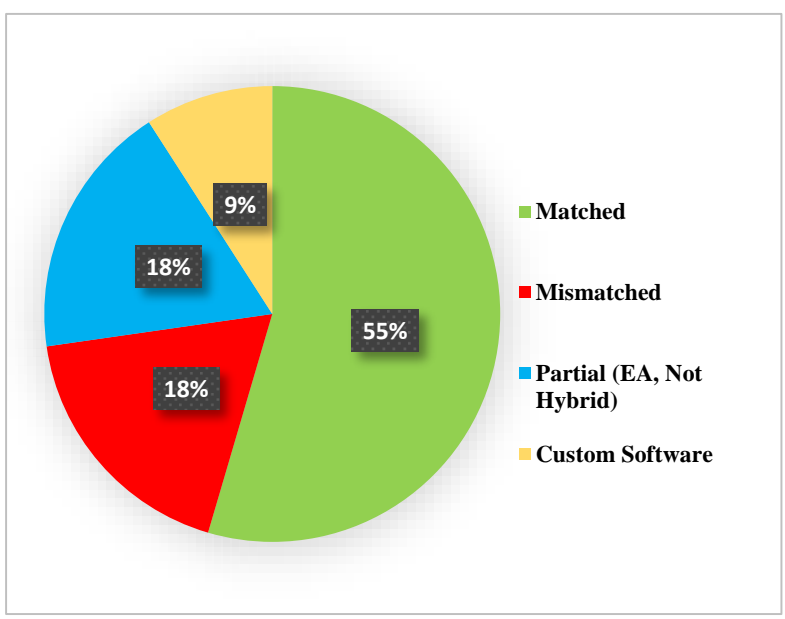

Fig. 2 Decision Support System Validation Results

\section{FUTURE STUDY}

The framework, developed in this study, is the first attempt of its kind. Therefore, it was developed as a prototype with the basic tools and constrains available. The said framework can be further improved in future, with the following additions.

Automation technologies such as Artificial Intelligence and Machine learning technologies can be integrated into the DSS, as possible algorithms for route optimization. This should allow the system to fetch online real-time data to update the optimization technique with the re-evaluation of the parameters. It can be achieved with the integration of adaptive signals, traffic control centers and vehicle navigation systems. Artificial intelligence techniques can also be utilized for selection of the routing algorithm, in addition to being a route optimization algorithm themselves. Another avenue for improvement is data availability and exploring relationships of variables and constraints with one another to achieve more refined results.

\section{CONCLUSION}

The objective of this research was to design and develop a framework for a universal DSS that is capable of recommending an appropriate route optimization method for MSW collection and disposal. The recommended method should yield a more effective optimal solution based on the available regional data. The framework's design is based on the contents of vehicle route optimization literature from 14 countries. The framework was developed to be flexible and accommodate different situations from the local data of the user. The DSS successfully predicted the suitable optimization 
technique for $73 \%$ of the tested researches, of which $18 \%$ were recommended an enhanced version of the original methods used. The latter shows the ability of the developed framework to provide the decision makers with a consultation that leads to an improved method compared to the ones which they have previously utilized.

The framework is expected to help the agencies/departments/ministries to select the appropriate route optimization tools for MSW collection according to their local conditions. Moreover, the framework can be applied with a working knowledge of available scenario. The proposed DSS has the potential to be enhanced further in terms of additional route optimization algorithms, data availability and relationships of variables with one another, and constraints to the decision support algorithm to achieve more refined results. Finally, automation technologies such as Artificial Intelligence and Machine learning technologies can be integrated into the DSS when more research is available with these methods in the future. This should allow the system to fetch online real-time data to update the optimization technique suggested to the client. It would produce a DSS capable of re-evaluating the current parameters when necessary.

\section{REFERENCES}

[1] Al Sabbagh, M. K., Velis, C. A., Wilson, D. C., \& Cheeseman, C. R., Resource Management Performance in Bahrain: A Systematic Analysis of Municipal Waste Management, Secondary Material Flows and Organizational Aspects, Waste Management \& Research, 30, 2012, pp. 813-824.

[2] Kaza, S., Yao, L. C., Bhada-Tata, P., \& Van Woerden, F., What a Waste 2.0 : A Global Snapshot of Solid Waste Management to 2050, Washington, DC: World Bank, 2018.

[3] Al-Jubori, K., \& Gazder, U., Framework for Route Optimization of Solid Waste Collection, Smart Cities Symposium, 2018 (pp. 179-184). Bahrain: The Institution of Engineering and Technology.

[4] Das, S., \& Bhattacharyya, B. K., Optimization of Municipal Solid Waste Collection and Transportation Routes, Waste Management, 43, 2015, pp. 9-18.

[5] Hareesh, K. B., Manjunath, N., \& Nagarajappa, D. P., Route Optimization of Municipal Solid Waste for Davangere City Using GIS, International Journal of Innovative Research in
Science, Engineering and Technology, 4, 2015, pp. 3834-3843.

[6] Jovičić, N. M., Bošković, G. B., Vujić, G., Jovičić, G., Despotović, M. Z., Milovanović, D. M., \& Gordić, D. R., Route Optimization to Increase Energy Efficiency and Reduce Fuel Consumption of Communal Vehicles, Thermal Science, 14, 2010, pp. 77-88.

[7] Dao-Tuan, A., Nguyen-Thi-Ngoc, A., NguyenTrong, K., Bui-Tuan, A., \& Dinh-Thi-Hai, V., Optimizing Vehicle Routing with Path and Carbon Dioxide Emission for Municipal Solid Waste Collection in Ha Giang, Vietnam, Industrial Networks and Intelligent Systems. INISCOM, 2017 (pp. 212-227), Ho Chi Minh City, Vietnam: Springer.

[8] O'Connor, D. L., Solid Waste Collection Vehicle Route Optimization for the City of Redlands, California, (Master's Thesis, University of Redlands). 2013, Retrieved from https://inspire.redlands.edu/gis_gradproj/201/

[9] Caric, T., \& Gold, H., Vehicle Routing Problem, Rijeka, Croatia: In-Teh., 2008

[10] Le Hoang, S., Optimizing Municipal Solid Waste Collection using Chaotic Particle Swarm Optimization in GIS Based Environments: A Case Study at Danang, Expert Systems with Applications, 41, 2014, pp. 8062-8074.

[11] Kytojoki, J., Nuortio, T., Braysy, O., \& Gendreau, M., An Efficient Variable Neighborhood Search Heuristic for Very Large Scale Vehicle Routing Problems, Computers \& Operations Research, 34, 2007, pp. 2743-2757.

[12] Maniezzo, V., Algorithms for Large Directed CARP Instances: Urban Solid Waste Collection Operational Support, Bolonha, Italy: University of Bologna, 2004.

[13] Tung, D. V., \& Pinnoi, A., Vehicle RoutingScheduling for Waste Collection in Hanoi, European Journal of Operational Research, 125, 2000, pp. 449-468.

[14] Huang, G. H., Sae-Lim, N., Liu, L., \& Chen, Z., An Interval-Parameter Fuzzy-Stochastic Programming Approach for Municipal Solid Waste Management and Planning. Environmental Modeling \& Assessment, 6, 2001, pp. 271-283.

[15] Maqsood, I., \& Huang, G. H., A Two-Stage Interval-Stochastic Programming Model for Waste Management Under Uncertainty, Journal of the Air \& Waste Management Association, 53, 2003, pp. 540-552.

[16] Wang, F. S., Deterministic and Stochastic Simulations for Solid Waste Collection 
Systems - A SWIM Approach, Environmental Modeling \& Assessment, 6, 2001, 249-260.

[17] Chalkias, C., \& Lasaridi, K., A GIS Based Model for the Optimisation of Municipal Solid Waste Collection: The Case Study of Nikea, Athens, Greece, WSEAS TRANSACTIONS on ENVIRONMENT and DEVELOPMENT, 5, 2009, pp. 640-650.

[18] Apaydin, O., \& Gonullu, T., Emission Control with Route Optimization in Solid Waste Collection Process: A Case Study, Sadhana, 33, 2008, pp. 71-82.

[19] Karadimas, N. V., Kolokathi, M., Defteraiou, G., \& Loumos, V., Municipal Waste Collection of Large Items Optimized with ARC GIS Network Analyst, Proceedings 21st European Conference on Modelling and Simulation, 2007 pp. 96-99. Prague, Czech Republic.

[20] Ferreira, J. A., Costa, M., Tereso, A., \& Oliveira, J. A., A Multi-Criteria Decision Support System for a Routing Problem in Waste Collection, International Conference on Evolutionary Multi-Criterion Optimization, 2015, pp. 388-402.

[21] Fan, X., Zhu, M., Zhang, X., He, Q., \& Rovetta, A., Solid Waste Collection Optimization Considering Energy Utilization for Large City Area, International Conference on Logistics Systems and Intelligent Management (ICLSIM), 2010, (pp. 1905-1909). Harbin: IEEE.

[22] Ismail, Z., \& Loh, S. L., Ant Colony Optimization for Solving Solid Waste Collection Scheduling Problems, Journal of Mathematics and Statistics, 5, 2009, pp. 199205.

[23] Nguyen-Trong, K., Nguyen-Thi-Ngoc, A., Nguyen-Ngoc, D., \& Dinh-Thi-Hai, V., Optimization of Municipal Solid Waste Transportation by Integrating GIS Analysis, Equation-Based, and Agent-Based Model, Waste Management, 59, 2017, pp. 14-22.

[24] Bani, M. S., Rashid, Z. A., Hamid, K. H., Harbawi, M. E., Alias, A. B., \& Aris, M. J., The Development of Decision Support System for Waste Management; a Review, World Academy of Science, Engineering and Technology, 49, 2009, pp. 161-168.

[25] Blazquez, C., \& Paredes-Belmar, G., Network Design of a Household Waste Collection System: A Case Study of The Commune of Renca in Santiago, Chile, Waste Management, 116, 2020, pp. 179-189.

[26] Bányai, T., Tamás, P., Illés, B., Stankevičiūtè, Ž., \& Bányai, Á., Optimization of Municipal
Waste Collection Routing: Impact of Industry 4.0 Technologies on Environmental Awareness and Sustainability, International Journal of Environmental Research and Public Health, 16, 2019, 634.

[27] Louati, A., Son, L. H., \& Chabchoub, H., Smart Routing for Municipal Solid Waste Collection: A Heuristic Approach, Journal of Ambient Intelligence and Humanized Computing, 10, 2019, pp. 1865-1884.

[28] Kamal, M. A., \& Youlla, D., Municipal Solid Waste Transportation Optimisation with Vehicle Routing Approach: Case Study of Pontianak City, West Kalimantan, IOP Conference Series: Earth and Environmental Science, 131, 2018 IOP Publishing Ltd.

[29] Nesmachnow, S., Rossit, D., \& Toutouh, J., Comparison of Multiobjective Evolutionary Algorithms for Prioritized Urban Waste Collection in Montevideo, Uruguay, Electronic Notes in Discrete Mathematics, 69, 2018, pp. 93-100.

[30] Akhtar, M., Hannan, M. A., Begum, R. A., Basri, H., \& Scavino, E., Backtracking Search Algorithm in CVRP Models for Efficient Solid Waste Collection and Route Optimization, Waste Management, 61, 2017, pp. 117-128.

[31] Assaf, R., \& Saleh, Y., Vehicle-Routing Optimization for Municipal Solid Waste Collection Using Genetic Algorithm: The Case of Southern Nablus City, Civil and Environmental Engineering Reports, 26, 2017, pp. 43-57.

[32] Le Hoang, S., \& Louati, A., Modeling Municipal Solid Waste Collection: A Generalized Vehicle Routing Model with Multiple Transfer Stations, Gather Sites and Inhomogeneous Vehicles in Time Windows, Waste Management, 52, 2016, pp. 34-49.

[33] Paul, K., Dutta, A., \& Krishna, A. P., A Comprehensive Study on Solid Waste Vehicle Routing and Tracking - A Case Study on Kolkata City, KSCE Journal of Civil Engineering, 20, 2016, pp. 137-144.

[34] Sanjeevi, V., \& Shahabudeen, P., Optimal Routing for Efficient Municipal Solid Waste Transportation by Using ArcGIS Application in Chennai, India, Waste Management \& Research, 34, 2016, pp. 11-21.

[35] Xue, W., \& Cao, K., Optimal Routing for Waste Collection: A Case Study in Singapore, International Journal of Geographical Information Science, 30, 2016, pp. 554-572.

[36] Malakahmad, A., Bakri, P. M., Mokhtar, M. R., \& Khalil, N., Solid Waste Collection Routes 
Optimization via GIS Techniques in Ipoh City, Malaysia, Procedia Engineering, 77, 2014, pp. 20-27.

[37] Kanchanabhan, T. E., Selvaraj, S., Sundaram, V. L., \& Mohaideen, J. A., Application of Geographical Information System (GIS) in Optimisation of Waste Collection for Alandur Municipality in South Chennai, India, International Journal of Environment and Waste Management, 7, 2011, pp. 395-410.

[38] Makan, A., Malamis, D., Assobhei, O., Loizidou, M., \& Mountadar, M., Solid Waste Management: Case of Collection and Vehicle Routing Problem in The City of Azemmour, Morocco, International Journal of Management Science and Engineering Management, 6, 2011, pp. 247-255.

[39] Apaydin, O., \& Gonullu, M. T., Route Optimization For Solid Waste Collection: Trabzon (Turkey) Case Study, Global NEST Journal, 9, 2007, pp. 6-11.

[40] Agha, S., Optimizing Routing of Municipal Solid Waste Collection Vehicles in Deir elBalah-Gaza Strip, The Islamic University Journal (Series of Natural Studies and Engineering), (14), 2006, pp. 75-89.

[41] Bhambulkar, A. V., \& Khedikar, I. P., Municipal Solid Waste (MSW) Collection Route for Laxmi Nagar By Geographical Information System (GIS), International Journal of Advanced Engineering Technology, 2, 2011, pp. 1-6.

[42] Dijkstra, E. W., A Note on Two Problems in Connexion with Graphs, Numerische Mathematik, 1, 1959, pp. 269-271.

[43] Kulkarni, R. V., \& Bhave, P., Integer Programming Formulations of Vehicle Routing Problems, European Journal of Operational Research, 20, 1985, pp. 58-67.

[44] Sulemana, A., Donkor, E. A., Forkuo, E. K., \& Oduro-Kwarteng, S., Optimal Routing of Solid Waste Collection Trucks: A Review of Methods, Journal of Engineering, 2018, pp. 112.

[45] Hannan, M. A., Arebey, M., Begum, R. A., \& Basri, H., Radio Frequency Identification (RFID) and Communication Technologies for Solid Waste Bin and Truck Monitoring System, Waste Management, 31, 2011, pp. 2406-2413.

[46] Hua, T. M., Nguyen, T. K., Van Dinh Thi, H., \& Thi, N. A., Towards a Decision Support System for Municipal Waste Collection by Integrating Geographical Information System Map, Smart Devices and Agent-Based Model, Proceedings of the Seventh Symposium on
Information and Communication Technology, 2016, pp. 139-146. Ho Chi Minh City: ACM.

[47] Santos, L., Coutinho-Rodrigues, J., \& Antunes, C. H., A Web Spatial Decision Support System for Vehicle Routing Using Google Maps, Decision Support Systems, 51, 2011, pp. 1-9.

[48] Author, Title of the Paper, International Journal of Science and Technology, Vol.X, No.X, 200X, pp. XXX-XXX.

[59] Author, Title of the Book, Publishing House, $200 \mathrm{X}$.

\section{Contribution of individual authors to the creation of a scientific article (ghostwriting policy)}

Ahmed Omar and Uneb Gazder, carried out the literature review, writing of original draft, review and editing

Ahmed Omar, carried out the data curation and formal analysis, validation and visualization of work Uneb Gazder and Khalil Juboori, devised the methodology and performed supervision of work Nedal Ratrout, took part in validation of work, and review and editing of writing

\section{Sources of funding for research presented in a scientific article or scientific article itself}

This research did not receive funding from any organization

\section{Creative Commons Attribution}

\section{License 4.0 (Attribution 4.0 \\ International , CC BY 4.0)}

This article is published under the terms of the Creative Commons Attribution License 4.0 https://creativecommons.org/licenses/by/4.0/deed.en US 